\title{
A Scenario-based Approach to Discuss the Future of Croatian Rural Areas: Developing the Conceptual Framework of the Croruris ProJeCT $^{1}$
}

Aleksandar Lukić and Petra RADELJAK KaUfManN, both Zagreb*

\section{Content}

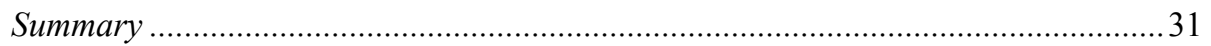

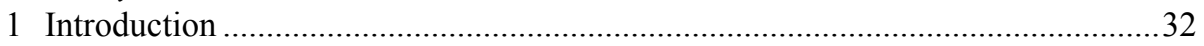

2 Development challenges of rural areas in Croatia.................................................33

3 Scenario-based studies of rural areas in Europe: selected examples.........................35

4 Developing a conceptual framework for discussing development

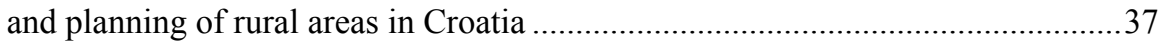

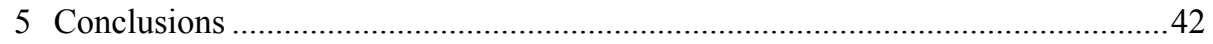

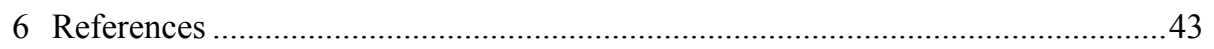

\section{Summary}

Rural areas account for almost $90 \%$ of the land and are home to almost half of the population, both in Croatia and the European Union (EU). They are still the most important food production zones in Europe, although this primary function has been challenged by numerous modernisation and globalisation processes and complemented by other economic, social, cultural, and environmental functions. Given their size,

$1 \quad$ This work has been supported by the Croatian Science Foundation under the project number 4513. Any opinions, findings, and conclusions or recommendations expressed in this material are those of the author(s) and do not necessarily reflect the views of Croatian Science Foundation.

* Aleksandar Lukić, PhD., Petra Radeljak Kaufmann, PhD., both University of Zagreb, Faculty of Science, Department of Geography, Marulićev trg 19, HR-10 000 Zagreb, Croatia; email: alukic@geog.pmf.hr; radeljak@geog.pmf.hr 
population number, functions, and variety of challenges they face, the question of future of rural areas is one of the most pressing issues in Europe today.

Although the majority of rural areas in Croatia face tremendous demographic and economic challenges, (to our knowledge) no scenario-based research has been done and only a few partial impact analyses have been conducted in recent Croatian agricultural policy. The goal of this paper is to identify main pillars of the conceptual framework for an interdisciplinary, scenario-based, study of Croatian rural futures CRORURIS. Therefore, an overview of recent development challenges of rural Croatia is offered, as well as selected examples of recent scenario studies of rural futures in Europe. Given that the main anticipated result of the CRORURIS study is the production of a set of alternative future scenarios for Croatian rural areas in 2030, with the goal of encouraging informed and evidence-based public debate on rural futures, three main pillars of the conceptual framework are described: the recognised diversity of rural areas in Europe and Croatia; the need to study rural areas in different spatial contexts; as well as the need to increase public awareness on the future of rural areas.

\section{Introduction}

Rural areas account for almost $80-90 \%$ of the land, depending on the definition used, and are home to almost half of the population, both in Croatia and the European Union (EU). They are still the most important food production zones in Europe, although this primary function has been challenged by numerous modernisation and globalisation processes and complemented by other economic, social, cultural, and environmental functions. As a result, we have witnessed the (re)emergence of heterogeneous and diversified rural areas, juxtaposing depopulation and land abandonment in some regions, and tourist development or agricultural intensification in others (WESTHOEK et al. 2006). Rural studies are becoming more and more important in international studies, and new conceptual frameworks for understanding rural change have been developed in both academic and political discourse. Given their size, population number, functions, and variety of challenges they face, the question of the future of rural areas is one of the most pressing issues in Europe today. This is evident from recent scenario-based approaches to study future trends and driving forces for rural Europe, both in academic and political discourse, on both national and EU levels (e.g. SCENAR 2020; EURURALIS).

Scenario method was introduced into future studies by Herman KAHN in the United States and DATAR (the Office for Regional Planning and Development) in France (GODET 2000). An early definition by KAHN \& WIENER sees scenarios as "hypothetical sequences of events constructed for the purpose of focusing attention on causal processes and decision points" (KAHN \& WIENER 1967, p. 6). USA and France were centres of development of scenarios in the decades following the Second World 
War. In the USA scenario method was originally used for military purposes, followed by application in public policy and corporate planning; in France, it was also developed for use in public policy, business, and urban and regional planning (La Prospective School) (Bradfield et al.,2005; Godet \& Roubelat 1996; Durance 2010; Durance \& Godet 2010). The often-cited success story is that of Royal Dutch/Shell (WACK 1985a, 1985 b) where scenario planning had an important role in predicting and dealing with the effects of oil shocks. Scenarios were used less in the 1980s, while in the 1990s they enjoyed a renewal of interest, connected with changes in corporations and also the use of scenarios for policy discussions by the public sector in Europe, as well as the NGO sector (Ringland 2006). VARUM \& MELo (2010) provided an overview of patterns in academic literature on scenario planning published in the last decades. Their study registered considerable growth in the number of articles published per year in the 1990s and 2000s, and over 70\% of the articles were published after 2000.

Scenarios have become a very important part of planning in business environments, technology foresight, public policy planning, socio-economic planning, environmental studies, as well as spatial planning. They have also been used on multiple spatial scales. There are numerous examples of scenarios in relation to research, planning and development of national territories, regions, urban and rural areas (e.g. ET2050 Territorial Scenarios and Visions for Europe 2014; ÖROK 2012; DE NIJS et al. 2004; ÖZKAYNAK 2008). Specifically in relation to spatial planning, one of the areas where scenarios are very important is strategic spatial planning, which has seen a revival of interest since the 1990s in many parts of Europe (AlbReCHTs et al. 2003).

The majority of rural areas in Croatia face tremendous demographic and economic challenges, and, despite this, no scenario-based research on rural areas in Croatia has been conducted (to our knowledge) and only few partial impact analyses have been conducted in recent Croatian agricultural policy (BROz et al. 2007; ERJAVEC et al. 2012). The goal of this paper is to identify main pillars of the conceptual framework for an interdisciplinary, scenario-based study of Croatian rural futures. Therefore, an overview of recent development challenges of rural Croatia will be offered, as well as selected examples of recent scenario studies of rural futures in Europe. Given that the main anticipated result of the CRORURIS study is the production of a set of alternative future scenarios for Croatian rural areas in 2030, with the goal of encouraging informed and evidence-based public debate on rural futures, three main pillars of the conceptual framework are described.

\section{Development challenges of rural areas in Croatia}

Rural areas in Croatia are generally seen as marginal to social, economic, political, and scholarly interests, which might seem surprising, as only half a century 
ago Croatia was a predominantly rural and agricultural country. Three quarters of its population lived in rural areas, and more than half of the population worked in agriculture (Рокоs 2002; ŽIvić 2002). In a relatively short period, from 1953 to 2001 , the percentage of rural population decreased from two thirds to $42-46 \%$ of total population (depending on definition used), and the percentage of agricultural population was reduced tenfold, from $56.1 \%$ to $5.5 \%$. The peak of the rural exodus was in the 1960s and 1970s, which occurred simultaneously with the development of industry and the tertiary sector, and an increase in employment abroad. General and agrarian policies were unfavourable for farmers' private properties, which, along with the long-term depopulation, deagrarianisation and pauperisation, triggered in the $19^{\text {th }}$ century by the economic and political crisis followed by overseas emigration, resulted in social and economic impoverishment of rural areas.

Consequently, rural areas in Croatia are almost synonymous with problem areas. More than one third of Croatian territory is home to less than $7 \%$ of the Croatian (mostly elderly) population. On average, rural areas are characterised by deep structural and dynamic disorders in demographic, social, and economic development, and stagnation in regional development. The cumulative effects thereof place increasing burdens on development and weaken the state's spatial and functional integration. The most marked crisis features can be observed in the karst periphery, including a part of the important strategic border zone (Pejnović 2004a; Pejnović 2004b). The Croatian War of Independence and the transition to a market economy were among the last very influential elements of the spatial and regional transformation of the country. Consequentially, most contemporary research emphasizes negative demographic, economic, and social features of the Croatian countryside at the beginning of the $21^{\text {st }}$ century (AKRAP 2002, p. 60; LAY 2002, p. 296; NeJAŠmić \& ŠTAMBUK 2003, p. 487; S̆TAMBUK 2002, p. 22; ŠTAMBUK \& MiŠETIĆ 2002; ŽIVIĆ 2002, p. 125; ŽupanČIĆ 2005a, p. 617).

However, the aforementioned processes differed significantly in their spatial effects, and they contributed to the heterogeneity of rural areas (LuKIĆ 2012). The role and importance of agriculture also differs significantly among the country's rural regions. During the Socialist period, prior to the 1991-1995 War of Independence, Croatia had been rather capable of covering most of the foodstuff needs of the country, thanks to well-developed industrial and service sectors. The transition period in the 1990s from planned to market economy, change of agricultural structure, liberalisation of domestic market, and war consequences have had strong impacts on the whole Croatian economy as well as on agriculture itself. The socio-economic situation until the year 2000 was characterised by general economic decline, migration of population, decreasing utilisation or destruction of agricultural resources (land and cattle), and decreasing productivity and economic efficiency (FrANIĆ \& KUMRIĆ 2008). In the last decade, agriculture still played an important economic role although the average national share in Gross Value Added is slightly above 4\%, in contrast to the share of total national employment of $15 \%$ (CBS 2013). Of the total utilised agricultural area 
(UAA), the greater share is covered by arable land (68\%) with maize and wheat as the main crops, and by permanent grasslands (27\%). The overall Croatian agri-food trade balance is constantly negative (from -457.7 million EUR in 2001 to $-1,121.2$ million EUR in 2011). Only a few agri-food products have a positive trade balance: fish, oilseeds, meat products, sugar and sugar confectionaries, beverages, and tobacco (FRANIć \& MiKuš 2013). Due to the national agricultural policy during the transition period the present agricultural structure is polarised (ŽUPANČIĆ 2005b; UNDP 2013). According to the last farm structure survey (2010), there were 233,300 total agricultural holdings covering 1,315,000 hectares of agricultural land (UAA), which makes 5.6 hectares of agricultural area per holding (MIKUŠ et al. 2010). The majority (99\%) are family farms, mostly small, fragmented, and semi-subsistent while other $1 \%$ is business entities. Almost $90 \%$ of the total amount of farms accounts for just one third of agricultural land; only $1 \%$ of farms have more than 70 hectares each, accounting for another third of agricultural land. The largest 33 farms account for $14 \%$ of utilised agricultural land. Aside from the Socialist past, war, and transition period, the fragmentation can also be ascribed to lax inheritance laws and unsolved ownership relationships. Many family farms are therefore not competitive or economically viable in the medium- or longterm perspectives (UNDP 2013; Franić \& MiKUŠ 2013).

\section{Scenario-based studies of rural areas in Europe: selected examples}

Recently, several scenario studies specifically targeting rural areas in Europe have appeared, on both EU and national levels, such as the EURURALIS project, SCENAR 2020, and a study of rural futures in England and Wales described in LowE \& WARD 2009. Independent of the professional or scientific fields, the basic dimensions of scenarios are driving forces and key uncertainties. Scenarios reflect different assumptions about how current trends will unfold, how critical uncertainties will play out, and which new factors will become important. Driving forces represent key factors, trends, or processes that propel the system forward determining the outcomes. Whether they are, or are not, invariant over time can represent critical uncertainties. Critical uncertainties reflect factors or processes with an important role in determining the unfolding of the scenarios, whose values or outcomes are difficult to anticipate (ROTHMAN 2008).

The EURURALIS project (1.0, 2.0, and 3.0) aims at developing a discussionoriented tool to support policy makers and stakeholders in discussions about the future of rural areas in the European Union, based on scientifically sound data and methodology. The EURURALIS toolbox links economic and biophysical domains as well as global and local scales (EURURALIS Factsheet 2010). The first methodological step was the 
elaboration of the general storylines, including the specification of driving forces such as demographic and economic trends, world trade regulations, consumer preferences, and various policies. Scenarios were developed using a $2 \times 2$ matrix consisting of four world views or development paradigms, and quantified with a chain of models on different scales (EURURALIS Methodology; Westhoek et al. 2006). The results of the project are the development and implementation of methodologies for policy assessment (e.g. new agro-biodiversity indicator, spatial policies) and an assessment of the impact of those policies. EURURALIS 3.0 is map-based and available as a website, allowing for easy interpretation of assessment results on multiple spatial scales (EURURALIS Factsheet 2010).

The initial SCENAR 2020 study was carried out in 2006 to identify and analyse long-term trends concerning demographic development and dynamics of rural areas, and the future of the agricultural economy including the environmental dimension for the European Union. Two years later the exercise was repeated. As with the initial study, in SCENAR 2020-II there were two sets of 'drivers' - exogenous and endogenous, assumed to influence the evolution of agriculture up to 2020. Exogenous drivers were ones that were not expected to be altered substantially by EU policy decisions within the set period, such as population growth, macro-economic growth, consumer preferences, agro-technology, environmental conditions, and world markets. Endogenous, or policy-related drivers, were expected to have a discernible effect within the SCENAR 2020-II time horizon; those were EU agricultural policy, enlargement decisions and implementation, World Trade Organisation (WTO) and selected EU bilateral agreements, renewable energy policy, and environmental policy. Three policy scenarios were proposed within the SCENAR 2020-II study: a "Reference" scenario; a "Conservative CAP" scenario; and a "Liberalisation" scenario (SCENAR 2020-II Executive summary 2009). The scenarios were compared in two steps. The first step was a macro-economic type of analysis - a modelling exercise that analysed the likely outcome of each scenario using simulation models and other quantitative analyses, complemented by qualitative analyses and expert judgement when necessary. A second type of analysis was the SWOT analysis approach, where a series of strengths and weaknesses associated with social and environmental conditions at the regional level were contrasted (SCENAR 2020-II Executive summary 2009).

The third important example is a study of alternative futures conducted for rural England from a social geographic perspective. Researchers identified predominant contemporary trends affecting rural areas and projected them forward by means of formal modelling. This led to a set of three 20-year scenarios for the English countryside aimed at stimulating public debate on rural futures (LOWE \& WARD 2009). They started by constructing a rural typology from an analysis of how specific social and economic characteristics were manifesting themselves throughout contemporary English rurality. A set of variables was selected to represent four dimensions; demography, economy, interactions between residential location and wider economy/society, and signs of rural symbolism. A cluster analysis produced seven statistically significant clusters or types 
of rural areas, and each rural district was assigned to one of them. The set of 15 variables was converted into a set of 11 dimensions representing different 'drivers' of change (or resistance to change). These dimensions together with the seven components of the rural typology provided a matrix base for the model. The matrix elements were calibrated, which required judgement on the degree to which each dimension would affect the different area types. After the model was created, the use of the Monte Carlo procedure resulted in a set of scenarios. Three 20-year scenarios were selected and labelled as "the Consumption Countryside", "the $21^{\text {st }}$ Century Good Life", and "the Rise of the Rurbs". Those preliminary scenarios were also subjected to examination and elaboration in a workshop of invited experts representing the voluntary sector, government departments, quangos, local authorities, and academics (LOWE \& WARD 2010).

\section{Developing a conceptual framework for discussing development and planning of rural areas in Croatia}

Considering current processes in rural Europe and Croatia, the main drivers of change of rural areas, and the characteristics of the scenario-based approach to discussing rural futures, three pillars of the conceptual framework for discussing rural futures in Croatia can be identified.

\subsection{Diversity of rural areas in Europe and Croatia - "If you've seen one rural place, you've seen one rural place” (OECD 2006)}

For decades, the main societal context and the principal economic driver in rural areas was agriculture. Consequently, agricultural policy has been used almost as a universal tool for planning and regulating countryside since the 1960s. But today it is becoming increasingly apparent that agriculture in many rural regions is not the main economic activity and that economic diversification into tourism and other activities has changed the ways in which rural areas are lived and perceived (BUTLER et al. 1998; Cawley \& Gillmor 2008; Hall et al. 2003; Ilbery 1998; SCENAR 2020; Woods 2005). Although agriculture remains the dominant form of land use in rural areas (RIENKS 2008), it has been challenged by numerous modernisation and globalisation processes and complemented by other economic, social, cultural, and environmental functions. The changing reality of rural Europe has triggered some important shifts in the Common Agricultural Policy (CAP) of the European Union. The most significant reforms to the CAP began in 1992, and in 2003 the link between subsidies and production was cut. We have also seen the development of Pillar II of the CAP 
focusing exclusively on a broader vision of rural development sensitive to regional and even local geographies and cultures. In general, planning and policy in rural areas has turned away from a sectoral (agricultural) basis and towards a place-based approach that supports economic performance, social inclusion, and environmental assets of rural localities (OECD 2006; SHUскSмiтh 2010). It became apparent that 'rural' does not describe a single, homogeneous entity (BRUNORI \& Rossi 2006; HalfaCree 2006; Cloke 2006; OECD 2006; RiENKS 2008; SCENAR 2020; Woods 2005). It takes many forms and the challenges that different areas face require intelligent, regionally targeted responses. In other words, it is dangerous to generalise about the countryside, because different areas face different problems. Policies and strategies for rural planning and development, in order to be effective, should recognise that diversity. In order to recognise the assets, understand the problems and take account of the diversity of rural areas, evidence-based rural policy is needed. For example, in the last decade England has introduced an evidence-based approach, starting with the introduction of rural definition in 2004, which takes in account criteria such as population density on a very small spatial level. This complex approach towards rurality has been further enhanced with much research conducted by different governmental bodies and agencies - the Commission for Rural Communities being a very important one (DEPARTMENT FOR Environment, Food and Rural Affairs 2007).

If we accept that the diversity and dynamics of rural areas are some of the key elements in their planning and development, then an important question is whether and how they are recognised and converted into action. How do we transfer a conceptual model into a workable, applicative instrument? LOWE \& WARD (2009) offered a possible solution in their quest to overcome shortcomings of recent future studies, namely: evaluating the basis of the scenarios produced (how they were constructed) and their excessively arbitrary, implausible, or nonspecific nature (LOWE \& WARD 2009 , p. 1320). They suggested developing the conceptual framework into a typology of rural areas based on multivariate analysis. Although their approach is certainly a "technically more systematic exercise as a replicable statistical approach set in a firm conceptual framework" the typological approach used is not a new idea. Typologies, especially those based on advanced multivariate techniques have been present in geography and other spatial studies since the mid-20 $0^{\text {th }}$ century (RoBINSON 2008). They became more prominent in rural studies in the 1980s. We have already established that, by that time, it was becoming clear that the diversity and the dynamics of rural areas are some of the key elements in their planning and development. Typologies have been used as an instrument for the identification of territorial differences, as well as for the systematisation, comparison, and analysis of collected information. The typology of rural areas in the European Commission document "The future of rural society" (1988), which recognised three standard problems of European rural areas (the pressure of modern life, rural decline, and marginalisation), and classified areas accordingly (integrated, intermediate, and remote rural areas), is probably still the most well-known (European Commission 1988). Later, in the 1990s and 2000s, typologies 
based on advanced statistical techniques and GIS were produced both in the European Spatial Development Perspective (ESDP) and in the European Spatial Planning Observation Network (ESPON) (Bengs \& Schmidt-Thomé 2006). Finally, descriptive rural area types recognised in the background document for the Territorial Agenda of the European Union 2020 (EUROPEAN Union 2011), arguably the most important political framework concerning spatial planning and territorial development, were the last in the line of typological analyses of European territory. The typology recognised four different territorial types: accessible rural territories in the metropolitan centres' surroundings; remote rural areas; internal rural peripheries; and traditional agricultural areas (EUROPEAN Union 2011, pp. 55-57).

A typology of rural areas in Croatia, based on the previously mentioned new understandings of diversified countryside, was developed at a very small administrative boundary level (statistical settlements, 6,620 non-urban units in 2001), and followed a place-based approach (LuKić 2012). Seven types of rural settlements were recognised (one being residual with $0.2 \%$ of total population): A - dynamic, structurally stronger rural and urbanised settlements (688 settlements, 747,054 people); B - accessible, commuting-dependent rural and urbanised settlements (638 settlements, 200,609 people); C - market-oriented agricultural rural and urbanised settlements $(1,710$ settlements, 522,234 people); D - economically diversified, mainly tourist rural and urbanised settlements (913 settlements, 267,833 people); E - rural and urbanised settlements of extensive agriculture and weaker demographic structure (1,380 settlements, 239,985 people); $\mathrm{F}$ - rural periphery (991 settlements, 58,317 people). The typology confirmed the strong diversification of rural areas in Croatia, and the need to consider their future trends in line with the place-based approach. The CRORURIS study requires the development of a new typology of rural areas as the one mentioned above is based mostly on data from 2001 and since then a new Census of Population has been conducted (2011). Furthermore, the presented typology was not developed in order to serve as a basis for projecting predominant trends affecting rural areas in the future. However, it offers both valuable methodological and empirical guidance.

\subsection{Rural areas in different spatial contexts}

Rural areas do not exist in vacuum: they should be viewed in their local and regional, as well as national and global contexts. Included in this is the relationship between rural and urban areas. This means bridging the gap between rural and regional development policies, as well as spatial land use and economic development plans and strategies (OECD 2006).

The snapshot of rural Croatia and the current state of agriculture reveals many structural and dynamic problems and asks for possible solutions. At the same time, a systematic conceptual framework for understanding the complex and changing reality of rural areas in Croatia, similar to the one developed in FP7 project DERREG, 
has not been developed (www.derreg.eu). That particular research emphasised that "globalisation is not a singular, monolithic and homogenising force... There is no one rural experience of globalisation, and no pre-determined outcomes. National, regional and local factors can all intervene to shape impacts and responses. The model holds that the geographical pattern of globalisation effects reflects the intersection of globalisation processes (such as market liberalisation or increased international mobility) with regional contexts and capacities."

Croatia's recent integration into the EU changes the geopolitical, economic and social contexts, and brings in wider regional and global forces for consideration in planning and development. Rural demographic patterns (especially out-migration of rural youth), macro-economic and agricultural market trends (further decrease in number of agricultural population, smaller number of farms, growth in average farm size, land abandonment, etc.), and environmental concerns and regulations (pressures and land use changes) are among the most important factors recognised in international studies that should be closely examined and related to the endogenous context. At the same time, decision-makers are becoming increasingly aware that one of the most important challenges is integrating various sectoral policies through horizontal and vertical coordination. Merging and coordinating different strategies and plans is certainly a possible way for achieving more efficient and harmonious spatial development (OECD 2006). These dimensions of sustainable rural and regional development have been recognised as important dimensions for rural and agricultural policies (e.g. SCENAR 2020): rural demographic patterns; economic and agricultural market transformations and trends; and environmental and land-use change.

Today the place-based approach is proclaimed as one of the cornerstones of the EU's polycentric and balanced development, which is considered to contribute to territorial cohesion, a new goal of the EU introduced by the Treaty of Lisbon (EUROPEAN UNION 2011, p. 4). The place-based approach is a very interesting concept because it reflects the changes in spatial planning theory and practice that have already been discussed in other discourses, mainly academic, for decades, such as: horizontal coordination, evidence-informed policy making, integrated functional area development, the subsidiarity principle through a multilevel governance approach, unleashing territorial potential through development strategies based on local and regional knowledge of needs, building on the specific assets and factors, which contribute to the competitiveness of places, utilising territorial capital to realise optimal solutions, and long-term development (EuROPEAN Union 2011, p. 5; AlLmendinger 2009).

Complexities of challenges in rural areas and their development require integration of knowledge from a range of disciplines. The multidimensional nature of the scenario method certainly has a potential in that aspect as well, as proven in their primary role in future studies. Scenarios are opening up the present, contouring the range of uncertainty, and offering alternatives (INAYATUlLaH 2008). Scenarios help envision various development possibilities and future end states. They help in 
perceiving interconnectedness within a system; being multidimensional, they mirror socio-geographical complexity thus avoiding overly simplistic views on development. Scenario method points to the importance of an interdisciplinary approach and coordination of development goals (PEGAN 2011). They should be a basis for developing ideas and testing conditions, so that they could serve in formulating and testing plans and strategies (RIKKONEN \& TAPIO 2009). Today, typologies of rural and urbanised areas are also common in spatial and regional strategies of European countries (MEREDITH 2007; Malinen s.a.; Centre for Local and Regional Studies - NUi Maynooth \& Brady Shipman Martin 2000; Iliopoulou et al. 2006; Berry et al. 2000; Meredith 2006; Harrington \& O’Donoghue 1998; Benaki et al. s.a.; Benaki et al. 2005; Reimer 2002; Perpar \& Kovačič 2002; Marsden 1998; Politecnico di Milano 1999; BaLlas et al. 2003). They might be especially useful in constructing the 'big picture' and thus overcoming the discord among the policies influencing development in rural areas at the national level (rural policy, regional policy, spatial/town, country planning systems, etc.). As evident from the concise literature overview of recent rural research in Croatia in Chapter 2, the focus was mostly on thematic studies, especially concerning demographic, social, and agricultural development. Although disciplinary-based studies concerning recent transformations of certain aspects of rural demography, society, economy, and environment in Croatia exist, to our knowledge no comprehensive interdisciplinary interpretative framework has been created.

\subsection{The need to increase public awareness and support discussion on rural futures}

Encouraging and supporting discussion about the future of rural areas in academic, decision-making and public discourse is important. Successful governance in rural areas requires new partnerships to be built. In order to achieve sustainable development in rural areas and decrease regional inequalities, a greater range of organisations should be involved in rural policy creation and delivery at regional and local levels. Building partnerships between public, private and voluntary sectors and encouraging participative and community-led forms of planning have brought numerous positive results on the local level. However, devolution of powers and the shift from government to governance requires that special care is taken to ensure clarity of roles, and that local authorities are empowered to understand and accept new models of planning and development (SHUCKSMITH 2010). Therefore, the scenariobased approach should encourage and support discussion about future of rural areas in academic, decision-making, and public discourse.

The final objective and the underlying purpose of the CRORURIS research is to provoke and support discussion on future development of rural areas in Croatia. As quoted in LOWE \& WARD (2009, p. 1320), several studies have shown that the act of thinking about possible futures can lead to an enhanced consciousness about the nature 
of collective problems and potential solutions. They conclude that scenario planning can, therefore, be a means to stimulate debate and inform social choices. Furthermore, FRIEDMANN argues for a locally based, in-depth exploration of strategic issues of urban development under different sets of assumptions or 'scenarios' as a way of probing the future in order to make more informed decisions in the present. The object of these studies would be to produce insights into prospective change in order to promote public debate (Friedmann et al. 2004).

\section{Conclusions}

Recently, several scenario studies specifically targeting rural areas in Europe appeared, on both EU and national levels (e.g. EURURALIS project 1.0, 2.0, and 3.0; SCENAR 2020; LowE \& WARD 2009). The EU level scenario SCENAR 2020 predicted numerous important trends for the future development of rural areas (SCENAR 2020, pp. 20-21). Because of the recognised need for a comprehensive model of understanding changes in the rural areas of Croatia, three pillars for developing a conceptual framework of the interdisciplinary CRORURIS study have been identified. The framework is based on: the recognised diversity of rural areas in Europe and Croatia; the need to study rural areas in different spatial contexts; and the need to increase public awareness on the future of rural areas. Therefore, the conceptual framework should reflect the interplay between the global context and driving forces on the one side, and national, regional and local factors on the other, in shaping the current and future state of Croatian rural areas. It should provide a set of well-documented and reasonable assumptions to help thinking about the possible future development of rural areas of Croatia, acknowledging the wider regional and EU context.

In the context of the CRORURIS study the newly created conceptual framework will be used to develop a methodological instrument for recognising specificities of rural places within the general spatial framework, in order to serve as a basis for modelling alternative scenarios. We expect that the CRORURIS study will greatly improve interdisciplinary and comprehensive views on the complexities of planning and development in rural areas of Croatia, and that application of its results will be of use in the real world and aid in decision-making processes. 


\section{References}

AKRAP A. (2002), Regionalne i naseljske značajke vitalnih procesa u hrvatskom seoskom stanovništvu. In: ŠtambuK M., Rogić I., MišETić A. (eds.), Prostor iza: kako modernizacija mijenja hrvatsko selo, pp. 59-90. Zagreb, Institut društvenih znanosti Ivo Pilar.

Albrechts L., Healey P., Kunzmann K.R. (2003), Strategic Spatial Planning and Regional Governance in Europe. In: Journal of the American Planning Association, 69, 2, pp. 113129.

Allmendinger P. (2009), Planning theory. Hampshire, Palgrave Macmillan.

Ballas D., Kalogeresis T., Labrianidis L. (2003), A comparative study of typologies for rural areas in Europe. Paper presented at the $43^{\text {rd }}$ European Congress of the Regional Science Association, Jyväskylä. <https://www.jyu.fi/ersa2003/cdrom/abstracts/a515.html> (25.1.2017)

Benaki V., Alexandrakis E., Apostolopoulos C. (s.a.), Entrepreneurial Parameters and Classification - Typology for Rural Areas. <http://www.stats.gov.cn/english/ICAS/papers/ P020071114317657343748.pdf> (10.3.2008)

Benaki V., Rontos K., Apostolopoulos C., Kazazis E., Christos M. (2005), Rural Areas in Greece: Definition, Typology and Data Needs for the Monitoring and Evaluation of Rural Development, National Statistical Service of Greece. Athens, National Statistical Service of Greece.

Bengs C., Schmidt-Thomé K. (eds.) (2006), Urban-rural relations in Europe. ESPON 1.1.2, Final report. Helsinki, Centre for Urban and Regional Studies, University of Technology.

Berry K.A., Markee N.L., Fowler N. Giewat G.R. (2000), Interpreting What is Rural and Urban for Western U.S. Counties. In: Professional Geographer, 52, 1, pp. 93-105.

Bradfield R., Wright G., Burt G., Cairns G., van der Heidden K. (2005), The origins and evolution of scenario techniques in long range business planning. In: Futures, 37, pp. 795-812.

Broz T., Grgić Z., Franić R., Nuavro M. (2007), Poljoprivreda i razvoj ruralnih područja. In: ŠvalJeK S. (ed.), Pristupanje Europskoj uniji: očekivani ekonomski učinci, pp. 87-95. Zagreb, Ekonomski institut.

BRUNORI G., Rossi A. (2006), Differentiating countryside: Social representations and governance in rural areas with high social density: The case of Chianti, Italy. In: Journal of Rural Studies, 23, 2, pp. 183-205. <doi:10.1016/j.jrurstud.2006.10.001>

Butler R., Hall C.M., Jenkins J. (eds.) (1998), Tourism and Recreation in Rural Areas. Chichester, John Wiley \& Sons.

Cawley M., Gillmor D.A. (2008), Integrated Rural Tourism: Concepts and Practice. In: Annals of Tourism Research, 35, 2, pp. 316-337. <doi:10.1016/j.annals.2007.07.011>

Centre for Local and Regional Studies - NUi Maynooth \& Brady Shipman Martin (eds.) (2000), Irish Rural Structure and Gaeltacht Areas (National Spatial Strategy). Maynooth - Dublin,, Centre for Local and Regional Studies - NUI Maynooth and Brady Shipman Martin.

Cloke P.J. (2006), Conceptualizing rurality. In: Cloke P., Marsden T., Mooney P.H. (eds.), Handbook of Rural Studies, pp. 18-28. London, Sage Publications Ltd.

Croatian Bureau of Statistics, CBS (ed.) (2013), National Accounts and Labour Force Survey - First Releases. Zagreb. <http://www.dzs.hr/default_e.htm> (27.10.2013) 
DE Nijs T.C.M., DE Niet R., Crommentuijn L. (2004), Constructing land-use maps of the Netherlands in 2030. In: Journal of Environmental Management, 72, pp. 35-42.

Department for Environment, Food and Rural Affairs (ed.) (2007), The Rural Development Programme for England 2007-2013 - a summary. <http://archive.defra.gov.uk/rural/rdpe/ progdoc.htm> (28.6.2011)

Developing Europe's Rural Regions in the Era of Globalization (DERREG). <http://www. derreg.eu/>

DURANCE P. (2010), Reciprocal influences in future thinking between Europe and the USA. In: Technological Forecasting \& Social Change, 77, pp. 1469-1475.

Durance P., Godet M. (2010), Scenario building: Uses and abuses. In: Technological Forecasting \& Social Change, 77, pp. 1488-1492.

ERJavec E., RednaK M., VolK T., BožIĆ M. (2012), Hrvatska poljoprivreda i Zajednička agrarna politika - okvir ekonomskih promjena i ocjena učinka po proizvodnima sektorima / Croatian agriculture and Common Agricultural Policy - the framework of economic changes and the estimated effect by production sectors. In: Pospišil M. (ed.), Proceedings of the $47^{\text {th }}$ Croatian $\& 7^{\text {th }}$ International Symposium on Agriculture, Opatija, February 1317, pp. 3-13. Zagreb, University of Zagreb, Faculty of Agriculture.

ET2050 Territorial Scenarios and Visions for Europe, Project 2013/1/19, Final Report, Executive Summary. <http://www.espon.eu/export/sites/default/Documents/Projects/ AppliedResearch/ET2050/FR/ET2050_FR-01_ExecutiveSummary.pdf $>$ (29.7.2015)

European Commission (ed.) (1988), The future of rural society. Commission communication transmitted to the Council and to the European Parliament. COM (88) 501 final, 28 July 1988. Bulletin of the European Communities, Supplement 4/88. <http://aei.pitt. $\mathrm{edu} / 5214 />(21.1 .2012)$

European Union (ed.) (2011), The Territorial State and Perspectives of the European Union, 2011 update, Background document for the Territorial Agenda of the European Union 2020. <http://www.euterritorial-agenda.eu/Reference\%20Documents/Forms/AllItems. $\operatorname{aspx}>(12.2 .2012)$

EURURALIS Factsheet (2010). <http://www.eururalis.eu/current/background/documents/ FactsheetNov2010.pdf $>(26.10 .2013)$

EURURALIS, Methodology. <http://www.eururalis.eu/version2/background/kader/index.html> (26.10.2013)

Franić R., KumRić O. (2008), Challenges faced by the agro-food sector in Western Balkans as regards its integration with the EU markets: the case of Croatia. In: REDNAK M. (ed.), Agriculture in Western Balkans and EU integration, pp. 33-46. Ljubljana, Društvo agrarnih ekonomistov Slovenije - DAES.

FRANIĆ R., MiKUŠ O. (2013), Chapter 10 Transformations in Croatian Agriculture and Agricultural Policy: Challenges and Opportunities within the European Context. In: OrTIZ-MiRandA D., Moragues-Faus A., Arnalte-Alegre E. (eds.), Agriculture in Mediterranean Europe: Between Old and New Paradigms (= Research in Rural Sociology and Development, 19), pp. 233-261. Bingley, Emerald Group Publishing Limited.

Friedmann J., with comments by Bryson J., Hyslop J., Balducci A., Wiewel W., Albrechts L. and a brief introduction by Healey P. (2004), Strategic Spatial Planning and the Longer Range. In: Planning Theory \& Practice, 5, 1, pp. 49-67.

Godet M. (2000), The Art of Scenarios and Strategic Planning: Tools and Pitfalls. In: Technological Forecasting and Social Change, 65, pp. 3-22. 
Godet M., Roubelat F. (1996), Creating the Future: The Use and Misuse of Scenarios. In: Long Range Planning, 29, 2, pp. 164-171.

Halfacree K. (2006), Rural space: constructing a three-fold architecture. In: Cloke P., Marsden T., Mooney P.H. (eds.), Handbook of Rural Studies, pp. 44-62. London, Sage Publications Ltd.

Hall D., Roberts L., Mitchell M. (eds.) (2003), New Directions in Rural Tourism. Aldershot, Ashgate.

Harrington V., O’Donoghue D. (1998), Rurality in England and Wales 1991: A Replication and Extension of the 1981 Rurality Index. In: Sociologia Ruralis, 38, 2, pp. 178-203.

Ilbery B. (ed.) (1998), The Geography of Rural Change. Harlow, Addison Wesley Longman Limited.

Iliopoulou P., Stratakis P., Tsatsaris A. (2006), Transformation of rural patterns in Greece in a European Regional Development Perspective (The Case of Crete), Paper presented at $46^{\text {th }}$ Congress of the European Regional Science Association "Enlargement, Southern Europe and the Mediterranean", Volos. <https://www.econstor.eu/bitstream/10419/118460/1/ ERSA2006_608.pdf> (25.1.2017)

INAYATULLAH S. (2008), Six pillars: futures thinking for transforming. In: Foresight, 10, 1, pp. 4-21.

KaHN H., Wiener A.J. (1967), The Year 2000: A Framework for Speculation on the Next ThirtyThree Years. New York, Macmillan.

LaY V. (2002), Prilozi osmišljavanju usmjeravanja razvitka ruralnih prostora Hrvatske na osnovama ekološke i gospodarske održivosti. In: Štambuk M., Rogić I., MišEtić A. (eds.), Prostor iza: kako modernizacija mijenja hrvatsko selo, pp. 289-304. Zagreb, Institut društvenih znanosti Ivo Pilar.

Lowe P., Ward N. (2009), England's Rural Futures: A Socio-Geographical Approach to Scenarios Analysis. In: Regional Studies, 43, 10, pp. 1319-1332.

Lukić A. (2012), Mozaik izvan grada - tipologija ruralnih i urbaniziranih naselja Hrvatske. Samobor, Meridijani.

MaLinen P. (2000), Rural Area Typology in Finland - marginality within rural areas. Contribution to Study Programme on European Spatial Planning, final report, Oulu.

MARSDEN T. (1998), New rural territories: Regulating the differentiated rural spaces. In: Journal of Rural Studies, 14, 1, pp. 107-117.

Meredith D. (2006), Identification of Rural Regions for Planning Purposes in Serbia. Dublin, The Rural Economy Research Centre.

Meredith D. (2007), Identification and Classification of Rural Spaces for Plannig Purposes in Data Poor Environment: Bosnia and Herzegovina. Dublin, The Rural Economy Research Centre.

Mikuš O., Mesić Ž., CerJaK M. (2010), Review of Agriculture and Agricultural Policy in Croatia. In: Volk T. (ed.), Agriculture in the Western Balkan Countries, pp. 93-121. Halle (Saale), Leibniz-Institut fur Agrarentwicklung in Mittel-und Osteuropa. <http://www.iamo.de/ dok/sr_vol57.pdf> (27.10.2013)

NeJAŠMić I., S̆TAMBuK M. (2003), Demografsko stanje i procesi u neurbanim naseljima Republike Hrvatske. In: Društvena istraživanja, 3-4, 65-66, pp. 469-493.

Organisation for Economic Cooperation and Development (OECD) (ed.) (2006), OECD Rural Policy Reviews: The New Rural Paradigm, Policies and Governance. Paris, OECD Publishing. 
ÖSTERREICHISCHE RAuMORDNUNGSKONFERENZ (ÖROK) (ed.), Raumszenarien Österreichs 2030. $<$ http://www.oerok.gv.at/raum-region/themen-und-forschungsbereiche/szenarienderraumentwicklung.html $>(19.10 .2012)$

ÖZKAYNAK B. (2008), Globalisation and local resistance: Alternative city developmental scenarios on capital's global frontier - the case of Yalova, Turkey. In: Progress in Planning, 70, pp. 45-97. < doi:10.1016/j.progress > (2008.04.002)

Pegan S. (2011), Scenariji prostornog razvoja. In: Butijer S., Magaš B., Obad Š́́itaroci M., KNIFIĆ Schaps H., TURNŠEK M. (eds.), Perspektive prostornog razvoja Republike Hrvatske

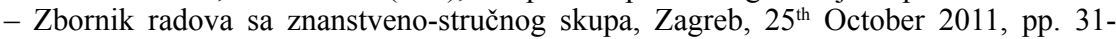
34. Zagreb, Ministarstvo zaštite okoliša, prostornog uređenja i graditeljstva, Hrvatska akademija znanosti i umjetnosti, Hrvatska komora arhitekata.

Pejnović D. (2004a), Depopulacija županija i disparitet u regionalnom razvoju Hrvatske. In: Društvena istraživanja, 4-5, 72-73, pp. 701-726.

Pejnović D. (2004b), Lika: Demographic Development under Peripheral Conditions. In: Hrvatski geografski glasnik, 66, 1, pp. 23-46.

Perpar A., KovačIČ M. (2002), Typology and development characteristics of rural areas in Slovenia. In: Dela, 17, pp. 85-99.

Pokos N. (2002), Metodologija izdvajanja seoskog stanovništva, njegov raspored i popisne promjene 1953.-2001. Godine. In: Štambuk M., Rogić I., MišEtić A. (eds.), Prostor iza: kako modernizacija mijenja hrvatsko selo, pp. 31-56. Zagreb, Institut društvenih znanosti Ivo Pilar.

Politecnico di Milano (ed.) (1999), A Typology of Rural Areas in Europe: Indicators on Strength and Weakness ofterritories and Selection of Areas (NUTS III). Milano, Politecnico di Milano.

ReImer B. (2002), Exploring Diversity in Rural Canada: Paper prepared for USDA, Economic Research Centre.

RiENKS W.A. (ed.) (2008), The future of rural Europe: An anthology based on the results of the Eururalis 2.0 scenario study. Wageningen, Wageningen University Research and Netherlands Environmental Assessment Agency.

RiKkonen P., TAPIO P. (2009), Future prospects of alternative agro-based bioenergy use in Finland - Constructing scenarios with quantitative and qualitative Delphi data. In: Technological Forecasting \& Social Change, 76, pp. 978-990.

Ringland G. (2006), Scenario Planning: Managing for the Future. Chichester, John Wiley \& Sons, Ltd.

Robinson G.M. (1998), Methods and Techniques in Human Geography. Chichester, John Wiley \& Sons, Ltd.

Rothman D.S. (2008), A Survey of Environmental Scenarios. In: Alcamo J. (ed.), Environmental Futures: The Practice of Environmental Scenario Analysis, pp. 37-65. Amsterdam, Elsevier.

SCENAR 2020-II, Executive summary for the 'Update of Analysis of Prospects in the Scenar2020 Study' (2009). <http://ec.europa.eu/agriculture/analysis/external/scenar2020ii/summary_ en.pdf> (26.10.2013)

Shucksmith M. (2010), Disintegrated Rural Development? Neo-endogenous Rural Development, Planning and Place-Shaping in Diffused Power Contexts. In: Sociologia Ruralis, 50, 1, pp. $1-14$. 
ŠTAmbuK M. (2002), Selo i modernizacija: kratka povijest nesporazuma. In: ŠTAMBUK M., Rogić I., MišEtić A. (eds.), Prostor iza: kako modernizacija mijenja hrvatsko selo, pp. 9-28. Zagreb, Institut društvenih znanosti Ivo Pilar.

Štambuk M., MišEtić A. (2002), Neki elementi socijalne i tehnničke infrastrukture hrvatskog sela. In: Štambuk M., Rogić I., MišEtić A. (eds.), Prostor iza: kako modernizacija mijenja hrvatsko selo, pp. 155-176. Zagreb, Institut društvenih znanosti Ivo Pilar.

Varum C.A., Melo C. (2010), Directions in scenario planning literature - A review of the past decades. In: Futures, 42, pp. 355-369.

VINTON L. (ed.) (2013), Fertile Ground for Development: Making the most of EU membership for Croatia's rural areas. A UNDP Policy Paper. New York, United Nations Development Programme (UNDP).

WACK P. (1985a), Scenarios: Uncharted Waters Ahead. In: Harvard Business Review (SeptemberOctober), pp. 73-89.

WACK P. (1985b), Scenarios: shooting the rapids. In: Harvard Business Review (NovemberDecember), pp. 139-150.

Westhoek H.J., van den Berg M., Bakkes J.A. (2006), Scenario development to explore the future of Europe's rural areas. In: Agriculture, Ecosystems and Environment, 114, pp. 7-20.

Woods M. (2005), Rural Geography: Processes, Responses and Experiences in Rural Restructuring. London, Sage Publications Ltd.

Žıvić D. (2002), Odabrane značajke demografske strukture seoskih naselja u Hrvatskoj 1953.1991. Godine. In: Štambuk M., Rogić I., MišEtić A. (eds.), Prostor iza: kako modernizacija mijenja hrvatsko selo, pp. 91-127. Zagreb, Institut društvenih znanosti Ivo Pilar.

ŽUPANČIĆ M. (2005a), Infrastrukturna opremljenost hrvatskih seoskih naselja. In: Sociologija sela, 169, 3, pp. 617-657.

ŽUPANČIĆ M. (2005b), Obiteljska poljoprivredna gospodarstva i ruralni razvitak u Hrvatskoj. In: Sociologija sela, 43/167, 1, pp. 171-194. 
